\title{
A SEARCH IN THE GUIANAS AND TRINIDAD FOR PREDATORY BEETLES OF THE BAIMBOO SCALES
}

By K. A. Bartletr, Associate Entomologist, Puerto Rico Experiment Station,

United States Department of Agriculture

\section{Bamboo Scales are Common Throughout the West Indies and Northern South America.}

Throughout the West Indies and in northern South America there are two species of scales which commonly attack bamboo, Asterolecanium bambusae (Bdv.) and A. miliaris (Bdv.). The former species generally confines its attack to the culms and larger branches, while the latter species usually attacks the leaves. In Puerto Rico both of these scales are particularly prevalent. Only one species of predatory beetle has been recorded as feeding on A. bambusae in Puerto Rico; Wolcott ${ }^{1}$ records the collection of Scymnillodes cyanescens var. violaceus Sicard. S. M. Dohanian, in an unpublished report, states that he observed a number of predators feeding on bamboo scales in Trinidad. Director Lee, of the Puerto Rico Experiment Station of the United States Department of Agriculture in a trip through the West Indies and northern South America, also observed considerable numbers of predatory beetles feeding on bamboo scales.

\section{Searci for Predatory Beetles was Made in British and Dutch Guinna and in Trinidad.}

In conjunction with a trip to British Guiana to obtain the Amazon fly, ${ }^{2}$ there was presented the possibility of making a search for predatory beetles of the hamboo scales. An appropriation from regular funds of the Puerto Rico Experiment Station also afforded an opportunity to visit Trinidad and Dutch Guiana in search of these predatory beetles. I wish to take this opportunity to express my thanks to L. D. Cleare, Entomologist, British Guiana Department of Agriculture, G. Stahel, Director Experiment Station, Dutch Guiana, and to Alan Pickles Entomologist Trinidad Department of Agriculture, for their cooperation in the search and collection of these predatory beetles.

${ }^{1}$ Wolcott, G. N. "Insectae Borinquenses". The Journal of Agriculture of the University of Puerto Rico, Vol. XX, No. 1. January 1936.

2 A coopcrative project financed 'oy' the Puerto Rico Sugar Producers Association and the Fajardo Sugar Co. 


\section{Etght Species of Predatory Beetles Were Collected and Shipped to Puerto Rico}

During a 4-day stay in Trinidad, six species of predatory beetles were found feeding on the bamboo seales $A$. bambusae and A. miliaris. The following species were collected in the vicinity of the Imperial College of Tropical Agriculture, St. Augustine, Trinidad, W. W. I.: Azya trinitatis Marsh., Cryptognatha nodiceps Marsh., Delphastus sp., Pentilia castanea Muls., and Pentilia sp. ${ }^{3}$

In Dutch Guiana during a 2-day search for predatory beetles, three species were found, namely Azya sp. probably trintatis and two species of Pentilia. ${ }^{3}$ These collections were made at a plantation on the opposite side of the river from Paramaribo, Dutch Guiana. Collections were made from bamboo growing along the banks of drainage canals. In some cases it was necessary to collect from dugout canoes, and this factor, together with the constant danger of poisonous snakes, made collection rather difficult.

In British Guiana three species were collected, Azya trinitatis, Pentilia castanea, and Pentilia sp. ${ }^{4}$. In addition to the above species, which were sent to Puerto Rico, there were collected a few specimens of Scymnillus sp. and Delphastus sp. and one specimen of Azya pontbrianti Muls. On one occasion on bamboo planted near a sugarcane field several specimens of Cycloneda sanguinea (L.) were observed feeding on $A$. miliaris. The shipments of predatory beetles sent by air express to Puerto Rico are summarized in Table 1.

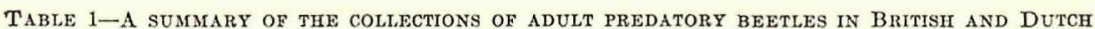
Guiana and Trinidad which were shipped by aIr express to PUerto Rico, giving LOCATION, DATE, SPECIES, AND NUMBER SHIPPED

\begin{tabular}{|c|c|c|c|}
\hline Species & $\begin{array}{c}\text { British Guiana } \\
\text { Sept. } 25 \text { and } \\
\text { Oct. } 2,1937\end{array}$ & $\begin{array}{c}\text { Dutch Guiana } \\
\text { Sept. 4, } 1937\end{array}$ & $\begin{array}{c}\text { Trinidad } \\
\text { Aug. 4, } 1937\end{array}$ \\
\hline 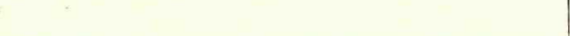 & No. shipped & No. shipped & No. shipped \\
\hline 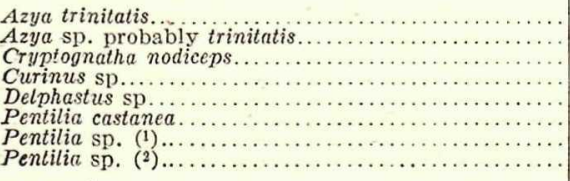 & 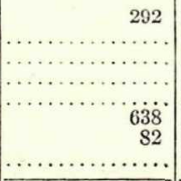 & 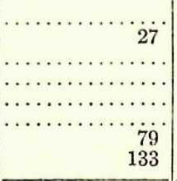 & $\begin{array}{r}10 \\
\text { i1 } \\
639 \\
536 \\
278 \\
24 \\
\ldots \ldots \ldots \ldots\end{array}$ \\
\hline Total... & 1,012 & 239 & 1,498 \\
\hline
\end{tabular}

(1) A dark brown species with red dots on wing covers.

(2) A solid dark brown species.

3 Determinations by E. A. Chapin, U. S. National Museum.

A dark brown species with red dots on wing covers. 


\section{Bamboo Scales Appeared to Be of Litrtle Importanct in THE COUN'rRIES VISTTED.}

While both bamboo scales, Asterolecanium bambusae and A. miliaris, were readily found in all the countries visited, it is of importance to record that the scale attacks were confined almost entirely to a single species of bamboo, Bambusa vulgaris Schrad; this was particularly true of $A$. bambusae found on the culms and of comparatively slight infestation. In Puerto Rico, where natural enemies are lacking, these scales are found attacking not only the common $B$. vulgaris, but also most of the more important species of bamboo which hav'e been recently introduced from other countries of the World.

The species of beetles collected were found in proportionate numbers to the adults shipped. Larvae of all the species collected were observed feeding on scales on both the culms and leaves. The adults were most abundant in the sunlight. It is hoped that the introduction and establishment of these beetles in Puerto Rico may result in a reduction of our bamboo scale infestations. 